\title{
Caveolin Proteins Are Essential for Distinct Effects of Membrane Estrogen Receptors in Neurons
}

\author{
Marissa I. Boulware, ${ }^{\star}$ Holly Kordasiewicz, ${ }^{\star}$ and Paul G. Mermelstein \\ Department of Neuroscience, University of Minnesota, Minneapolis, Minnesota 55455
}

It has become widely accepted that along with its ability to directly regulate gene expression, estradiol also influences cell signaling and brain function via rapid membrane-initiated events. Many of these novel signaling processes are dependent on estrogen receptors (ERs) localized to the neuronal membrane. However, the mechanism(s) by which ERs are able to trigger cell signaling when targeted to the neuronal membrane surface has yet to be determined. In hippocampal neurons, we find that caveolin proteins are essential for the regulation of CREB (cAMP response element-binding protein) phosphorylation after estradiol activation of metabotropic glutamate receptor (mGluR) signaling. Furthermore, caveolin-1 (CAV1) and CAV3 differentially regulate the ability of estradiol to activate two discrete signaling pathways. $\mathrm{ER} \alpha$ activation of mGluR1a is dependent on CAV1, whereas CAV3 is necessary for $\operatorname{ER} \alpha$ and $\operatorname{ER} \beta$ activation of mGluR2/3. These results are consistent with previous reports in non-neuronal cells, implicating the importance of caveolin proteins in rapid estrogen signaling. In addition, the functional isolation of distinct estrogen-sensitive signaling pathways by different caveolin proteins suggests novel mechanisms through which the membrane-initiated effects of estradiol are orchestrated.

Key words: estradiol; metabotropic glutamate receptors; CREB; MAPK; L-type calcium channel; hippocampus

\section{Introduction}

Estradiol elicits changes in gene expression through binding of its cognate receptors. Estradiol can act on two distinct intracellular receptors, estrogen receptor $\alpha(\mathrm{ER} \alpha)$ and $\mathrm{ER} \beta$, both of which mechanistically operate as ligand-activated transcription factors (Couse and Korach, 1999; Klinge, 2001). In addition to its genomic actions, estradiol has also been shown to exert various effects on cell function via rapid, membrane-initiated events (McEwen and Alves, 1999). A number of mechanisms underlying rapid estrogen action have been described (Kelly and Wagner, 1999; Kelly et al., 1999; Toran-Allerand et al., 2002; Qiu et al., 2003; Revankar et al., 2005; Vasudevan et al., 2005; Wu et al., 2005), including the steroid binding to membrane-localized ER $\alpha$ and ER $\beta$ (Razandi et al., 1999; Watson et al., 1999; Belcher and Zsarnovszky, 2001; Wade et al., 2001; Levin, 2002; Abraham et al., 2004).

We have recently characterized in hippocampal neurons two distinct intracellular signaling pathways that, while activated by estradiol at the neuronal membrane, ultimately lead to regulation of the transcription factor cAMP response element-binding protein (CREB) (Boulware et al., 2005). The first pathway involves

Received April 12, 2007; revised July 10, 2007; accepted July 30, 2007.

This work was supported by National Institutes of Health Grant NS41302 (P.G.M.). We thank Dr. E. Levin for EGFP-S522A ER $\alpha$, Drs. R. Massol and T. Kirchhausen for EGFP-CAV1, and Dr. R. Y. Tsien for EYFP. We also thank Dr. Bill Engeland for suggestions on this manuscript.

${ }^{*} M$.I.B. and H.K. contributed equally to this work.

Correspondence should be addressed to Dr. Paul G. Mermelstein, Department of Neuroscience, University of Minnesota, 6-145 Jackson Hall, 321 Church Street Southeast, Minneapolis, MN 55455. E-mail: pmerm@umn.edu.

H. Kordasiewizz's present address: Ludwig Institute for Cancer Research and Departments of Medicine and Neuroscience, University of California at San Diego, 9500 Gilman Drive, La Jolla, CA 92093.

DOI:10.1523/JNEUROSCI.1647-07.2007

Copyright $\odot 2007$ Society for Neuroscience $\quad 0270-6474 / 07 / 279941-10 \$ 15.00 / 0$
$\mathrm{ER} \alpha$ activation of metabotropic glutamate receptor la (mGluR1a), leading to mitogen-activated protein kinase (MAPK)-dependent CREB phosphorylation. The second pathway involves $\mathrm{ER} \alpha$ and $\mathrm{ER} \beta$ activation of $\mathrm{mGluR} 2 / 3$ signaling, resulting in a decrement of L-type calcium channel-mediated CREB phosphorylation. Although we have outlined these signaling pathways in detail, it is unclear how $\operatorname{ER} \alpha$ and $\operatorname{ER} \beta$ are localized to the neuronal membrane surface to initiate these responses.

In non-neuronal cells, membrane-localized ERs have been shown to localize within caveolae, distinct subcellular compartments within the plasma membrane (Kim et al., 1999; Chambliss et al., 2000). There are three caveolin isoforms (CAV1-3), which are not only crucial for the structural integrity of caveolae but also aid in the anchoring and compartmentalization of assorted signaling molecules (Krajewska and Maslowska, 2004; Williams and Lisanti, 2004). Outside the nervous system, ER $\alpha$ was demonstrated to physically interact with CAV1 (Schlegel et al., 1999, 2001); this interaction was necessary for the trafficking of $\mathrm{ER} \alpha$ to the membrane surface (Razandi et al., 2002). A putative role for caveolin proteins in neuronal estrogen signaling is particularly intriguing because caveolae have been demonstrated to take part in the localization and functioning of mGluRs and L-type calcium channels (Burgueno et al., 2004; Balijepalli et al., 2006; Couchoux et al., 2007), key players in our model of estrogen action within the hippocampus.

Recent studies have confirmed the expression of caveolins in brain (Cameron et al., 1997; Galbiati et al., 1998; Ikezu et al., 1998b; Mikol et al., 1999) and have been linked to the regulation of various neuronal processes, including hippocampal plasticity (Braun and Madison, 2000; Gaudreault et al., 2005). With this in mind, we sought to determine whether, in hippocampal neurons, 
caveolin proteins play a critical role in the membrane-initiated effects of $\operatorname{ER} \alpha$ and $E R \beta$. We present data that CAV1 is required for $\mathrm{ER} \alpha-\mathrm{mGluR} 1 \mathrm{a}$ signaling. In contrast, CAV3 is essential for $\mathrm{ER} \alpha / \mathrm{ER} \beta$ coupling to $\mathrm{mGluR} 2 / 3$. These results indicate an essential role for caveolins in the membrane-initiated actions of estradiol within the nervous system.

\section{Materials and Methods}

Cell culture. CA3-CA1 hippocampal pyramidal neurons were cultured from female 1- to 2-d-old rat pups as described previously (Mermelstein et al., 2000), using a protocol approved by the Animal Care and Use Committee at the University of Minnesota. Chemicals were purchased from Sigma (St. Louis, MO) unless stated otherwise. Following decapitation, the CA3-CA1 region of the hippocampus was isolated after removal of the dentate gyrus in ice-cold modified HBSS containing 20\% fetal bovine serum (FBS; HyClone, Logan, UT) and (in mM) 4.2 $\mathrm{NaHCO}_{3}$ and 1 HEPES, pH 7.35, 300 mOsm. The tissue was then washed and digested for $5 \mathrm{~min}$ in a trypsin solution (type XI; $10 \mathrm{mg} / \mathrm{ml}$ ) containing $137 \mathrm{~mm} \mathrm{NaCl}, 5 \mathrm{~mm} \mathrm{KCl}, 7 \mathrm{~mm} \mathrm{Na}_{2} \mathrm{HPO}_{4}, 25 \mathrm{~mm}$ HEPES , and $1500 \mathrm{U}$ of DNase, $\mathrm{pH}$ 7.2, $300 \mathrm{mOsm}$. After additional washes, tissue was dissociated and pelleted twice by centrifugation $(180 \times g$ for $10 \mathrm{~min})$ to remove contaminants. Cells were then plated $\left(\sim 6.4 \times 10^{4}\right.$ viable cells/well $)$ onto $10 \mathrm{~mm}$ coverslips (treated with Matrigel to promote adherence; BD Biosciences, San Jose, CA) and incubated for $15 \mathrm{~min}$ at room temperature. Two milliliters of minimum essential medium (MEM; Invitrogen, Grand Island, NY) containing $28 \mathrm{~mm}$ glucose, $2.4 \mathrm{~mm} \mathrm{NaHCO}_{3}, 0.0013 \mathrm{~mm}$ transferrin (Calbiochem, La Jolla, CA), $2 \mathrm{~mm}$ glutamine, and $0.0042 \mathrm{~mm}$ insulin with 1\% B-27 supplement (Invitrogen) and 10\% FBS, pH 7.35, $300 \mathrm{mOsm}$, were added to each coverslip. To inhibit glial growth, $1 \mathrm{ml}$ of medium was replaced with a solution containing $4 \mu \mathrm{M}$ cytosine $1-\beta-\mathrm{D}-$ arabinofuranoside and 5\% FBS $24 \mathrm{~h}$ after plating. Seventy-two hours later, $1 \mathrm{ml}$ of medium was replaced with modified MEM solution containing 5\% FBS. Gentamicin ( $2 \mu \mathrm{g} / \mathrm{ml}$; Invitrogen) was added to all media solutions to eliminate bacterial growth.

Drugs. The drugs used were as follows: $17 \beta$-estradiol ( $1 \mathrm{~nm}$ ); tetrodotoxin (TTX; $1 \mu \mathrm{M}$ ); D(-)-2-amino-5-phosphonopentanoic acid (AP-5; $25 \mu \mathrm{M}$; Tocris, Ellisville, MO); (RS)-3,5-dihydroxyphenylglycine (DHPG; $50 \quad \mu \mathrm{M} ; \quad$ Tocris); $(2 R, 4 R)$-4-aminopyrrolidine-2,4dicarboxylate (APDC; $10 \mu \mathrm{M}$; Tocris); 4,4',4' -(4-propyl-[1 H]-pyrazole1,3,5-triyl)trisphenol (PPT; $1 \mathrm{nm;} \mathrm{Tocris);} \mathrm{2,3-bis(4-hydroxyphenyl)-}$ propionitrile (DPN; $10 \mathrm{nM}$; Tocris); and 2-methyl-6(phenylethynyl)pyridine hydrochloride (MPEP; $5 \mu \mathrm{M}$; Tocris).

$P C R$. Detection of caveolin proteins in hippocampal cultures was performed using standard procedures. To stabilize mRNA, cultured neurons [8 d in vitro (8 d.i.v.)] were first placed in RNA later (Qiagen, Valencia, CA). RNA was then isolated using a standard kit (RNAeasy Mini kit; Qiagen), followed by the reverse transcription of the mRNA into cDNA (QuantiTect; Qiagen).

For verification of small interfering RNA (siRNA) efficiency, real-time PCR (qPCR) was used. cDNA was generated as explained above, followed by qPCR amplification using the DyNAmo HS SYBR Green master mix (New England Biolabs, Ipswich, MA). All qPCRs were performed and analyzed using the DNA Engine Opticon 2 (Bio-Rad, Hercules, CA) and standardized to $\beta$-actin. The critical cycle threshold was set at 10 SDs above baseline. PCRs for individual cDNA samples were performed in triplicate, and overall experiments were repeated at least twice. The thermal cycling program included an initial denaturing step at $95^{\circ} \mathrm{C}$ for $15 \mathrm{~min}$, followed by 45 cycles consisting of a $10 \mathrm{~s}$ denaturing step at $94^{\circ} \mathrm{C}$, annealing for $30 \mathrm{~s}$ at $60^{\circ} \mathrm{C}\left(56^{\circ} \mathrm{C}\right.$ for CAV1), and extension for $30 \mathrm{~s}$ at $72^{\circ} \mathrm{C}$. After each extension, fluorescent intensity was measured at $75^{\circ} \mathrm{C}$.

The upper and lower primer sequences for CAV1 (GenBank accession number NM_031556) were 5' -GCAGTTGTACCGTGCATCAAGAG-3' (nucleotides 385-407) and 5'-CGGATATTGCTGAATATCTTGCC-3' (nucleotides 490-512), yielding a predicted product size of $127 \mathrm{bp}$. Primer sequences for CAV2 (GenBank accession number NM_131914)

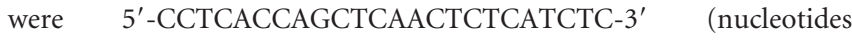
124-147) and 5' -CAGATGTGCAGACAGCTGAGG-3' (nucleotides
$318-338$ ), yielding a predicted product size of $214 \mathrm{bp}$. The primer sequences for CAV3 (GenBank accession number NM_019155) were 5' GGAGATAGACTTGGTGAACAGAGA-3' (nucleotides 60-83) and 5'CAGGGCCAGTGGAACACC-3' (nucleotides 241-258), yielding a predicted product of size $198 \mathrm{bp}$. The primers used for $\beta$-actin were (GenBank accession number NM_03144) 5'-AGGCCCCTCTGAACCCTAAG-3' (nucleotides 120-139) and 5'-CCAGAGGCATACAGGGACAAC-3' (nucleotides 217-238), yielding a predicted product size of $118 \mathrm{bp}$. All PCR primers were synthesized by Operon (Huntsville, $\mathrm{AL})$. PCR products were sequenced for verification.

Western blot. Cells were lysed with buffer containing $62.5 \mathrm{~mm}$ Tris, $2 \%$ SDS, $10 \%$ sucrose, and a protease inhibitor mixture (Complete Mini EDTA-free; Roche, Indianapolis, IN). The lysate was kept on ice for 5 $\mathrm{min}$, followed by brief vortexing and a $5 \mathrm{~min}$ sonication. The lysates were then heated at $95^{\circ} \mathrm{C}$ for $5 \mathrm{~min}$ with lithium dodecyl sulfate loading buffer ( $25 \%$ of total volume) and $\beta$-mercaptoethanol (10\% of total volume). Proteins were separated on a $4-12 \%$ Bis-Tris gel (Invitrogen), followed by transfer to a nitrocellulose membrane. A Tris-buffered saline (TBS) solution containing $10 \%$ milk and $1 \%$ BSA was used to block the membranes ( $1 \mathrm{~h}$, room temperature) before incubating them overnight at $4^{\circ} \mathrm{C}$ with the appropriate antibody (in TBS solution containing 1\% milk, 1\% BSA, and $0.1 \%$ Tween 20). Primary antibodies used were against CAV1 (1:200; BD Biosciences), CAV2 (1:200; BD Biosciences), CAV3 (1:200; $\mathrm{BD}$ Biosciences), and flotillin (1:25,000; BD Biosciences). The following day, the membrane was washed for $1 \mathrm{~h}$ with a TBS solution containing $0.1 \%$ Tween 20 and incubated for $1 \mathrm{~h}$ with a secondary antibody conjugated to horseradish peroxidase (1:12,500; Pierce, Rockford, IL). After another $1 \mathrm{~h}$ wash period, the membrane was incubated in a chemiluminescent substrate (Super Signal; Pierce) and exposed to X-Omat XB-1 film (Kodak, Rochester, NY). Experiments were repeated to verify results.

DNA constructs. The enhanced green fluorescent protein (EGFP)tagged mutant ER $\alpha$ (S522A) was provided by E. R. Levin (University of California, Irvine, CA). The EGFP-tagged CAV1 clone was provided by Drs. R. Massol and T. Kirchhausen (Harvard University, Boston, MA). Generation of dominant-negative CAV1 (dnCAV1; P132L substitution) was performed using a QuikChange II site-directed mutagenesis kit (Stratagene, La Jolla, CA). Primers for mutagenesis were $5^{\prime}$ CATCTGGGCAGTTGTGCTGTGCATTAAGAGTTTCC-3' and 5' $^{\prime}$ GGAAACTCTTAATGCACAGCACAACTGCCCAGATG-3'. CAV3 was PCR amplified from rat lung CDNA using the following primers: $5^{\prime}-$ CCTCACAATGATGACCGAAGAG-3' and 5'-GCTTTAGCCTTCCCTTCGCAGC- $3^{\prime}$. The product was then cloned into a TOPO (Invitrogen) vector, followed by its digestion out with $K p n I$ and $X h o I$. These sites were then used to insert CAV3 into the pYFP-N vector (provided by R. Y. Tsien, University of California, San Diego). Using techniques similar to creating dnCAV1, generation of dnCAV3 (P104L) was performed using the QuikChange II site-directed mutagenesis kit and the following primers: 5'-GGGCCGTGGTGCTCTGCATTAAGAGCTACC-3' and 5'-GGTAGCTCTTAATGCAGAGCACCACGGCCC-3'. All vectors were verified by direct sequencing.

Immunocytochemistry. The immunocytochemistry protocols followed those described previously (Mermelstein et al., 2000; Boulware et al., 2005). Briefly, cultured hippocampal neurons ( 9 d.i.v.) were incubated in a Tyrode's solution containing TTX $(1 \mu \mathrm{M})$ and D-AP-5 $(25 \mu \mathrm{M})$ at room temperature for $2.5-3 \mathrm{~h}$, with the solution being replaced halfway through the incubation period. Cell stimulations (and drug exposure durations before fixation) were performed as follows: vehicle (5 min); estradiol (5 min); $20 \mathrm{~mm} \mathrm{~K}^{+}$(3 min); estradiol and $20 \mathrm{~mm} \mathrm{~K}^{+}$(5 min estradiol alone followed by $3 \mathrm{~min}$ estradiol in $20 \mathrm{~mm} \mathrm{~K}^{+}$). mGluR agonists were also applied for $5 \mathrm{~min}$; when required to isolate $\mathrm{mGluR} 1 \mathrm{a}$, the mGluR5 antagonist MPEP was applied 15 min before and during stimulation. Cells were fixed for $20 \mathrm{~min}$ after stimulation using ice-cold $4 \%$ paraformaldehyde (Electron Microscopy Sciences, Ft. Washington, PA) in PBS containing 4 mm EGTA. After three PBS washes, permeabilization of cells was achieved by a 5 min incubation in a $0.1 \%$ Triton X-100 (VWR Scientific, West Chester, PA) solution. After three more washes, cells were blocked at $37^{\circ} \mathrm{C}$ for 30 min in PBS containing $1 \%$ BSA and $2 \%$ goat serum (Jackson ImmunoResearch, West Grove, PA). The cells were then 
A

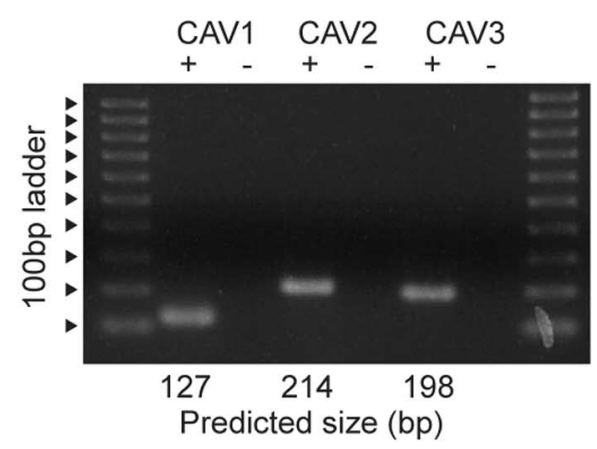

B

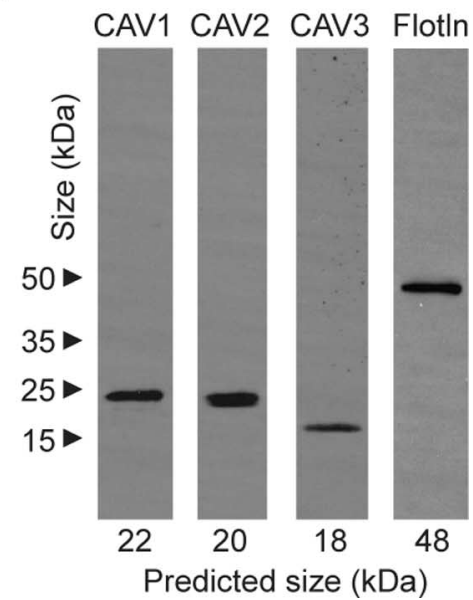

tamicin to prevent bacterial growth. The next day, transfected neurons were either mock treated or stimulated with $1 \mathrm{~nm}$ estradiol for $5 \mathrm{~h}$, followed by their lysis and subjection to an assay for luciferase expression. Experiments were replicated to verify results.

siRNA transfections. All siRNA reagents were obtained from Dharmacon (Lafayette, CO) unless stated otherwise. Cultured hippocampal neurons were cotransfected 7 d.i.v. with ON-TARGETplus SMARTpool siRNAs for rat CAV1, rat CAV3, or control siRNAs against no known gene target, in addition to the siGLO transfection indicator. Transfection protocols followed the manufacturer's instructions, except cells were incubated with $250 \mu \mathrm{l}$ of the transfection mixture and incubated at $37^{\circ} \mathrm{C}$ for $5 \mathrm{~h}$. After transfection, cells were washed once with DMEM (Invitrogen) before being placed back into their original medium. Based on siGLO fluorescence, $>90 \%$ of the cultured cells took up the siRNA. To assay relative changes in mRNA abundance, cells were processed $24 \mathrm{~h}$ after transfection for qPCR. For the Western blot and immunocytochemistry experiments, cells were used $48 \mathrm{~h}$ after transfection.

incubated at $4^{\circ} \mathrm{C}$ overnight in block solution containing a monoclonal antibody directed against serine 133 phosphorylated CREB (pCREB; 1:300; Upstate Biotechnology, Lake Placid, NY), and to identify individual cell morphology, a polyclonal antibody targeting microtubuleassociated protein 2 (MAP2; 1:500; Calbiochem). The following day, cells were washed three times and incubated for $1 \mathrm{~h}$ at $37^{\circ} \mathrm{C}$ in block solution containing CY5- and rhodamine RedX-conjugated secondary antibodies for visualization of MAP2 and pCREB, respectively (Jackson ImmunoResearch). After washing off excess secondary antibody, cells were mounted using the antiquenching and mounting medium Citifluor (Ted Pella, Redding, CA). Nuclear fluorescent intensities for pCREB ( $n=\sim 25$ cells per group) were acquired using a Yokogawa (Newnan, GA) spinning-disc confocal system mounted to an Olympus (Tokyo, Japan) IX-70 inverted microscope and attached to a 12-bit digital camera (Hamamatsu Photonics, Hamamatsu City, Japan). Data were quantified using MetaMorph software (version 6.0; Universal Imaging, Downington, PA).

The confocal excitation and detection settings (i.e., laser intensity, image acquisition time, etc.) for each experiment were determined using coverslips stimulated with $20 \mathrm{mM} \mathrm{K}^{+}$. Inter-coverslip variability was accounted for by subjecting two coverslips to each treatment. Data were acquired from coverslips in a random order. For image acquisition, neurons were selected randomly using MAP2 fluorescence, allowing the experimenter to remain blind to pCREB intensities. Images were captured through the approximate midline of each cell. During data analysis, the MAP2 staining was used to draw a region of interest (ROI) outlining the nucleus of each neuron. The ROI was then transferred to the pCREB image, and average fluorescence intensities within the nucleus were recorded. For all experiments, images were background subtracted. Each experiment was performed at least three times to verify results.

Luciferase-based gene reporter assays. Cultured neurons were transfected 8 d.i.v. with a luciferase-based reporter ( $1 \mu \mathrm{g}$ of DNA per coverslip) of estrogen response element (ERE)-dependent transcription using a calcium phosphate-based method (Deisseroth et al., 1998; Weick et al., 2003). Once transfected, cells were incubated in serum-free DMEM (Invitrogen) supplemented with insulin-transferrin-selenium-A (ITS; Invitrogen), $1 \% \mathrm{~B}-27$, and $2 \mu \mathrm{g} / \mathrm{ml}$ gentamicin to prevent bacterial growth. The following day, cells were lysed and assayed for luciferase expression using a standard luminometer (Monolight 3010; PharMingen, San Diego, CA). In separate experiments, cultured neurons were cotransfected 8 d.i.v. with ERE-luciferase and either EGFP wild-type $\operatorname{ER} \alpha$ or EGFPS522A ER $\alpha$. After transfection, cells were again incubated overnight in serum-free DMEM supplemented with ITS, $1 \%$ B-27, and $2 \mu \mathrm{g} / \mathrm{ml}$ gen-
Statistics. Immunocytochemistry experiments were analyzed using ANOVAs (F values) and Bonferroni's multiple comparison post hoc tests. Luciferase data were analyzed using a Student's $t$ test. In experiments with a large number of groups, differences in the effect of estradiol before and after experimental treatment are highlighted with arrowed brackets. Statistical differences between all treatment groups are depicted within each figure as different alphabetical characters. Probability values $<0.05$ were considered a priori as significant.

\section{Results}

\section{Expression of CAV1-3 in hippocampal cultures}

Caveolins are the principal scaffolding component of caveolae microdomains in the plasma membrane of various cell types. Although previously thought to be primarily expressed in muscle, epithelial, and endothelial cells, the presence of caveolins in brain has recently been described. With CAV1 necessary for the trafficking and membrane localization of ER $\alpha$ in non-neuronal cells, we sought to determine whether caveolins can also regulate membrane signaling of estrogens in brain. Our initial experiments were to therefore verify the expression of caveolin proteins within cultured hippocampal neurons. PCR analysis of cDNA derived from hippocampal cultures revealed the presence of all three members of the caveolin family (CAV1-3) (Fig. 1A), and direct sequencing confirmed the identity of the three PCR products. To verify expression of endogenous caveolin protein in our cultures, cell lysate was subjected to Western blotting. CAV1-3 were all detected, along with the protein flotillin, which was used as a positive control for detection of membrane-associated proteins (Fig. 1B).

\section{A single point mutation in ER $\alpha$ inhibits estradiol-induced CREB phosphorylation}

In hippocampal neurons, stimulation of membrane-localized ERs leads to the glutamate-independent activation of mGluRs (Boulware et al., 2005). More specifically, activation of ER $\alpha$ leads to mGluRla signaling, ultimately triggering MAPK-dependent CREB phosphorylation. In contrast, estradiol activation of either $\mathrm{ER} \alpha$ or $\mathrm{ER} \beta$ results in $\mathrm{mGluR} 2 / 3$ signaling and subsequent attenuation of L-type calcium channel-dependent CREB phosphory- 
A

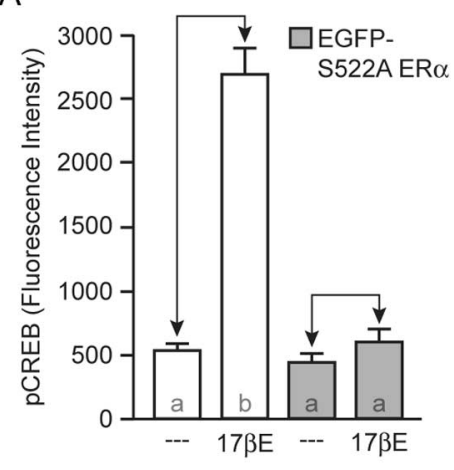

B

C

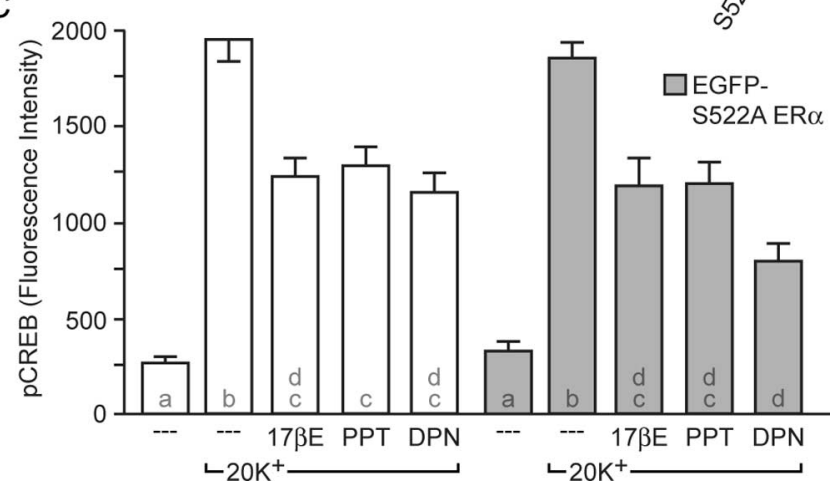

Figure 2. A single amino acid substitution in ER $\alpha$ disrupts estradiol-dependent CREB phosphorylation without affecting two other actions of estradiol. $A$, Transfection of cultured hippocampal neurons with EGFP-S522A ER $\alpha$, a construct that inhibits CAV1-mediated ER $\alpha$ membrane trafficking in non-neuronal cells, blocked estradiol-induced CREB phosphorylation ( $F=$ 61.66). B, EGFP-S522A ER $\alpha$ activates ERE-dependent transcription ( $t=5.87)$. C, EGFP-S522A ER $\alpha$ did not effect estradiol-mediated attenuation of L-type calcium channel-dependent CREB phosphorylation $(F=31.88)$. Both the $E R \alpha(P P T, 1 \mathrm{~nm})$ and $\operatorname{ER} \beta$ (DPN, $10 \mathrm{~nm}$ ) agonists were effective in the presence of EGFP-S522A ER $\alpha$ to attenuate depolarization-induced CREB phosphorylation. In this and all subsequent figures, alphabetical characters within each bar indicate statistical differences between groups $(p<0.05)$, and differences in the effect of estradiol before and after experimental treatment are indicated by the arrowed brackets. Error bars depict SEM. $17 \beta$ E, $17 \beta$-Estradiol.

lation. We sought to determine whether caveolin proteins regulate these two distinct signaling processes. In our initial investigations, hippocampal neurons were transfected with DNA encoding EGFP-tagged $\mathrm{ER} \alpha$, in which the receptor contained a single amino acid substitution (EGFP-S522A ER $\alpha$ ). In nonneuronal cells, the serine to alanine exchange leads to a decrease in ER $\alpha$ membrane localization and disrupts localization with CAV1 (Razandi et al., 2002). Functionally, this mutant specifically decreases the effects of estrogens on the rapid signaling processes in Chinese hamster ovary $(\mathrm{CHO})$ cells. Conversely, S522A ER $\alpha$ acts similar to the wild-type receptor when measuring ERE-driven gene expression (Razandi et al., 2002). We hypothesized that expression of EGFP-S522A ER $\alpha$ in hippocampal neurons would affect the actions of estradiol on CREB phosphorylation.

As described previously, a 5 min application of estradiol (1 nM) results in a significant increase in CREB phosphorylation (Fig. $2 A$, open bars). In contrast, expression of EGFP-S522A ER $\alpha$ abolished estradiol-induced CREB phosphorylation (Fig. 2A, shaded bars). The effect of EGFP-S522A ER $\alpha$ was specific to estradiol-induced CREB phosphorylation. For example, neurons transfected with EGFP-S522A ER $\alpha$ exhibited heightened ERE- dependent transcription compared with EGFP-transfected controls (Fig. $2 B$ ). In separate experiments, when compared with the overexpression of wild-type EGFP-tagged ER $\alpha$, EGFP-S522A $\mathrm{ER} \alpha$ was $91.8 \pm 14.3 \%$ as effective in driving estradiol-mediated ERE-based gene expression.

Intriguingly, EGFP-S522A ER $\alpha$ did not alter the actions of estradiol after L-type calcium channel-dependent CREB phosphorylation. In control neurons, a $3 \min 20 \mathrm{mM} \mathrm{K}^{+}$depolarization leads to a significant increase in CREB phosphorylation (Fig. $2 C)$. This effect is attenuated by either estradiol or specific ER $\alpha$ (PPT, $1 \mathrm{~nm}$ ) or ER $\beta$ (DPN, $10 \mathrm{~nm}$ ) agonists (Fig. 2C, open bars). Of note, we have previously found that this concentration of DPN does not activate ER $\alpha$ under these conditions (Boulware et al., 2005), consistent with previous reports (Meyers et al., 2001; Escande et al., 2006). In contrast to its effect on estradiol-induced CREB phosphorylation, EGFP-S522A ER $\alpha$ did not inhibit ER signaling on depolarization-induced CREB phosphorylation (Fig. 2C, shaded bars). This ability to independently regulate these two previously defined estradiol-sensitive signaling pathways became the focus of our remaining experiments.

\section{ER $\alpha$-induced activation of mGluR1a is dependent on CAV1}

Because the S522A mutant is thought to act as a dominant negative to membrane-initiated estrogen effects, principally because of disruption of ER $\alpha$ interactions with CAV1, we next determined whether CAV1 is critical in estradiol-induced CREB phosphorylation. Hippocampal neurons were next transfected with a dominant-negative form of CAV1 (EGFP-dnCAV1). A single amino acid substitution (P132L) in this protein disrupts the proper localization and trafficking of endogenous CAV1 (Lee et al., 2002). Hippocampal neurons transfected with EGFPdnCAV1 did not exhibit estradiol-induced CREB phosphorylation (Fig. 3A). In contrast, estradiol still attenuated L-type calcium channel-dependent CREB phosphorylation.

As mentioned, estradiol-induced CREB phosphorylation is mediated via activation of mGluR1a. Previous reports have established both molecular and functional interactions between CAV1 and mGluRla (Burgueno et al., 2004). Therefore, an important control was to determine whether EGFPdnCAV1 would influence mGluR1a signaling to CREB. As shown in Figure $3 B$, neurons transfected with EGFP-dnCAV still exhibited an increase in CREB phosphorylation after a 5 min stimulation with the mGluR1a agonist DHPG $(50 \mu \mathrm{M})$. Because DHPG activates both mGluR1 and mGluR5, cells in this experiment were pretreated with the mGluR5 antagonist MPEP $(5 \mu \mathrm{M})$. These experiments suggest that CAV1 is necessary for $\mathrm{ER} \alpha$ activation of mGluR1a but not the downstream process of mGluR1a signaling to CREB.

To confirm the observed effects of EGFP-dnCAV1, we implemented an additional experimental approach by introducing siRNAs targeted against CAV1. We first verified the effectiveness of the siRNAs to knockdown CAV1 mRNA. As shown in Figure 4A, transfection of hippocampal cultures with CAV1 siRNAs led to an $\sim 98 \%$ loss in CAV1 mRNA compared with cultures transfected with control siRNAs (siControl). Furthermore, we were able to detect a corresponding reduction in CAV1 protein (Fig. $4 B)$. Here, flotillin was used as a loading control. Functionally, transfection of CAV1 siRNAs blocked estradiol-induced CREB phosphorylation, whereas estradiol attenuation of L-type calcium channel-dependent CREB phosphorylation was again unaltered (Fig. 4C). As in the previous figure, we determined whether mGluR1a signaling to CREB was preserved. Consistent with previous findings, knockdown of CAV1 did not affect 
A

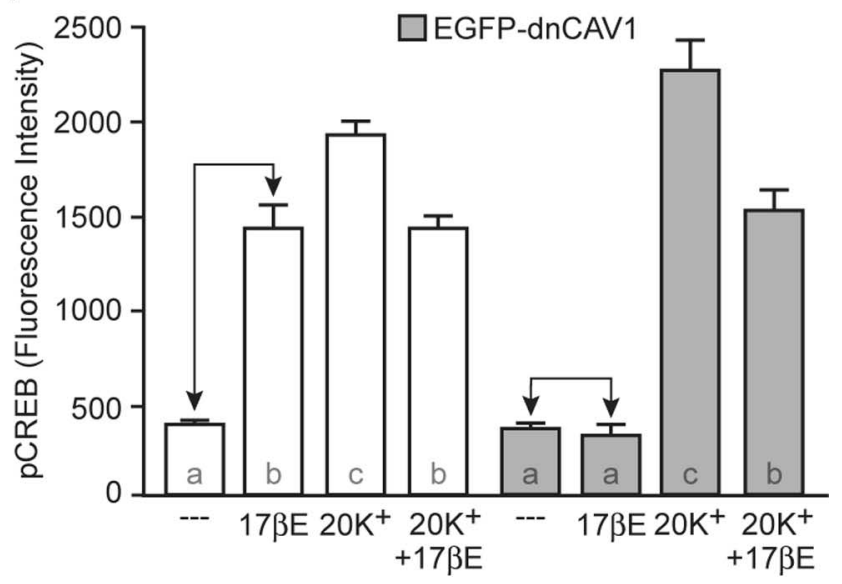

B

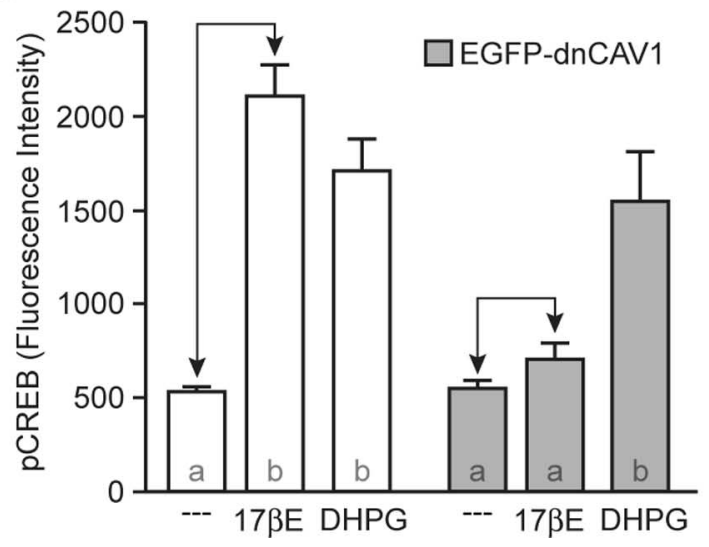

Figure 3. $\operatorname{dnCAV1}$ inhibits estradiol-induced CREB phosphorylation. $\boldsymbol{A}$, Transfection of EGFP-dnCAV1 eliminated estradiol-induced CREB phosphorylation $(F=71.54)$. Estradiol attenuation of L-type calcium channel-dependent CREB phosphorylation was unaffected. $\boldsymbol{B}$, EGFPdnCAV1 also did not affect mGluR1a-mediated (DHPG, $50 \mu \mathrm{m}$ ) CREB phosphorylation ( $F=$ 21.77). $17 \beta \mathrm{E}, 17 \beta$-Estradiol.

mGluRla-induced CREB phosphorylation (Fig. 4D). As a final control, we examined whether siRNAs against CAV1 would somehow affect CAV3 expression. Knockdown of CAV1 did not significantly alter the expression of CAV3 mRNA $(110.9 \pm 5.2 \%$ vs siControl) or protein (data not shown). Collectively, these results suggest that the expression of CAV1 in hippocampal pyramidal neurons is crucial for $\mathrm{ER} \alpha$-mGluR1a signaling, underlying estradiol-induced CREB phosphorylation. Additionally, CAV1 does not involve ER $\alpha$ and ER $\beta$ coupling to mGluR2/3. Our final experiments were designed to ascertain the mechanism by which this second signaling pathway is controlled.

\section{Estradiol-mediated activation of $\mathrm{mGluR} 2 / 3$ is reliant on CAV3}

Individual caveolae are formed by CAV1 or CAV3 (Kirkham et al., 2005). In cardiac (and skeletal) muscle, L-type calcium channels are localized to CAV3-based caveolae (Balijepalli et al., 2006; Couchoux et al., 2007). Because estradiol activation of mGluR2/3 results in the attenuation of L-type calcium channel-dependent CREB phosphorylation, we hypothesized that the effects of estrogen in hippocampal neurons on L-type calcium channels is regulated by CAV3. Using similar approaches to those listed above, we next tested this hypothesis.

As with CAV1, a single amino acid substitution (P104L) ren-
A

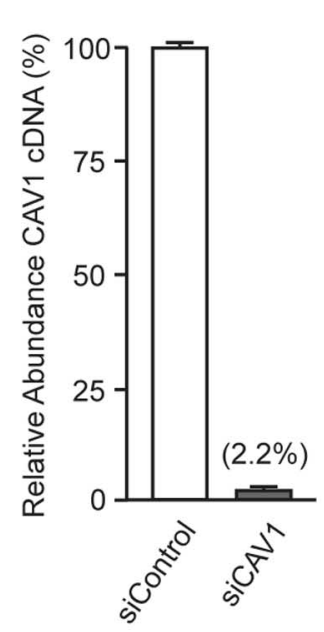

B

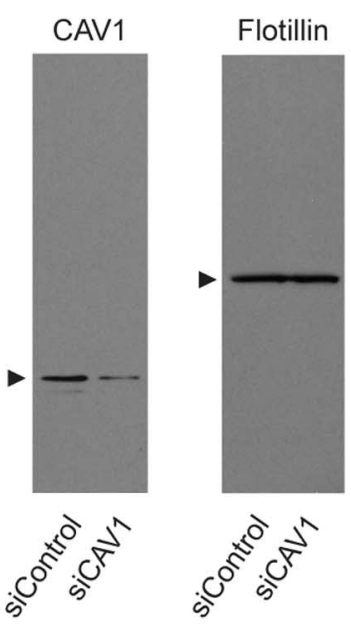

C
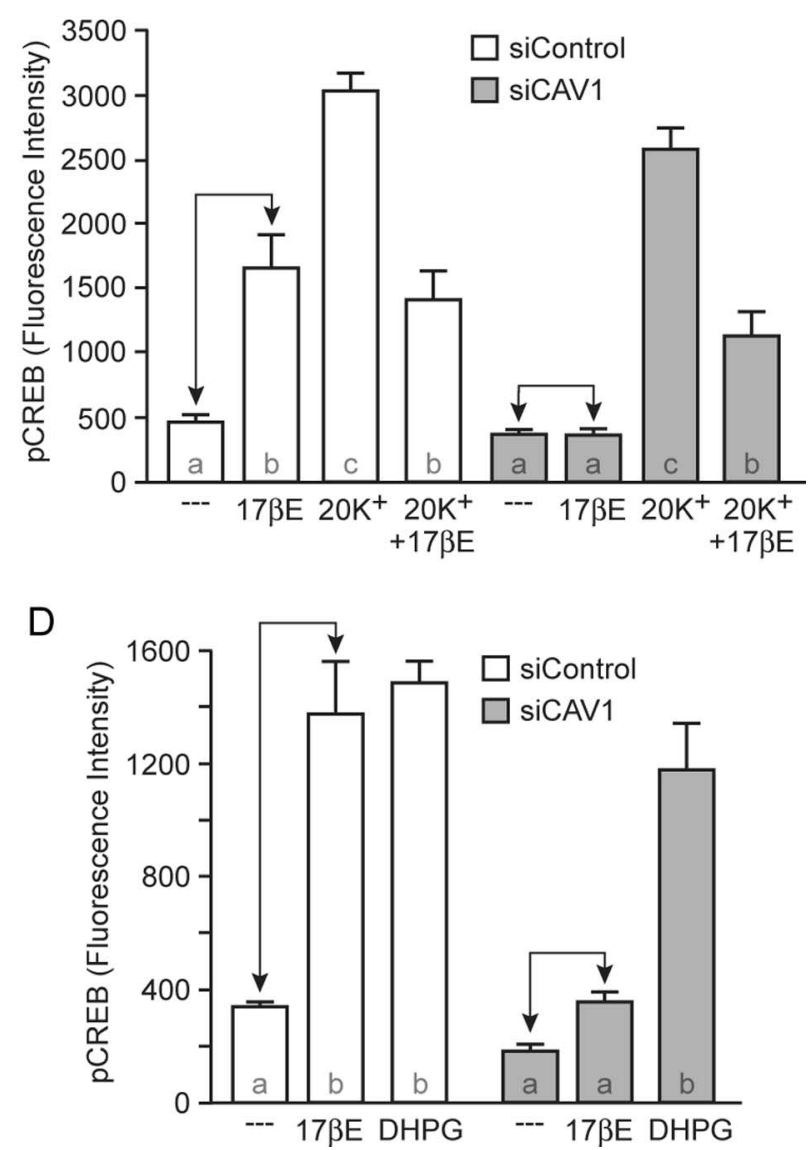

Figure 4. CAV1 expression is necessary for estradiol-induced CREB phosphorylation. $\boldsymbol{A}$, Transfection of hippocampal cultures with siRNAs targeting CAV1 (siCAV1) resulted in an $\sim 98 \%$ knockdown in CAV1 mRNA compared with cultures transfected with siControl. B, A corresponding decrease in CAV1 protein was observed after transfection of siCAV1. Flotillin was used as a loading control. C, Estradiol-mediated CREB phosphorylation was eliminated in cells transfected with siCAV1 $(F=41.27)$, without affecting estradiol inhibition of depolarizationinduced CREB phosphorylation. $\boldsymbol{D}$, Transfection of siCAV1 did not affect mGluR1a-mediated CREB phosphorylation $(F=30.43)$. 17 $\beta \mathrm{E}$, $17 \beta$-Estradiol.

ders a dominant-negative variant of CAV3 [dnCAV3 (Ohsawa et al., 2004)]. Expression of enhanced yellow fluorescent protein (EYFP)-dnCAV3 in hippocampal neurons eliminated the effect of estradiol on $20 \mathrm{mM} \mathrm{K}^{+}$depolarization, without altering estradiol-induced CREB phosphorylation (Fig. 5A). Further- 


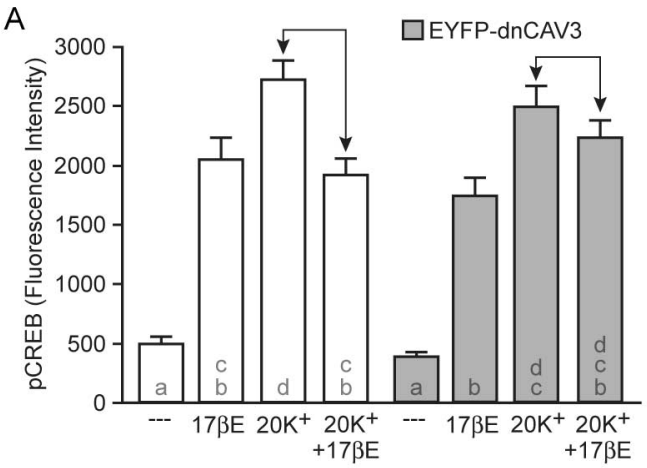

B

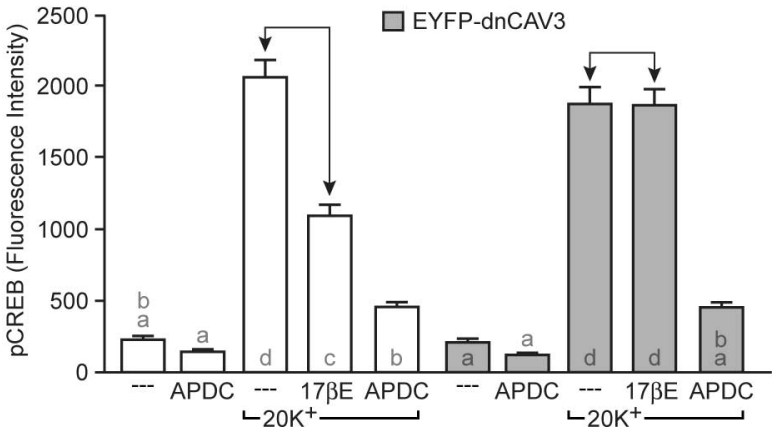

Figure 5. dnCAV3 inhibits estradiol regulation of L-type calcium channel-dependent CREB phosphorylation. $A$, Estradiol attenuation of L-type calcium channel-dependent CREB phosphorylation $(F=34.52)$ was abolished after transfection of EYFP- dnCAV3. Conversely, EYFPdnCAV3 had no effect on estradiol-induced CREB phosphorylation. $B$, Transfection of dnCAV3 had no effect on APDC-induced attenuation of depolarization-induced CREB phosphorylation $(F=126.0)$, suggesting that estradiol signaling was being disrupted upstream of $\mathrm{mGluR2} / 3$. $17 \beta$ E, $17 \beta$-Estradiol.

more, the mGluR2/3 agonist APDC $(10 \mu \mathrm{M})$ still attenuated L-type calcium channel CREB phosphorylation (Fig. 5B), suggesting the actions of EYFP-dnCAV3 were specific to $\mathrm{ER} \alpha / \mathrm{ER} \beta$ coupling to $\mathrm{mGluR} 2 / 3$.

To verify the importance of CAV3 in $\mathrm{ER} \alpha / \mathrm{ER} \beta$ interactions with mGluR2/3, we once again used siRNA. Transfection with siRNAs targeting CAV3 led to a $96 \%$ decrease in CAV3 mRNA and a subsequent loss in CAV3 protein (Fig. 6A,B). CAV3 siRNA did not significantly affect CAV1 mRNA ( $93.7 \pm 18.9 \%$ vs siControl) or protein expression (data not shown). Furthermore, the reduction in CAV3 expression eliminated the effect of estradiol on L-type calcium channel-mediated CREB phosphorylation (Fig. 6C). However, under these conditions, depolarization-induced CREB phosphorylation was also attenuated (Balijepalli et al., 2006; Couchoux et al., 2007). Therefore, as with previous experiments, it was necessary to determine whether agonist-induced activation of mGluR2/3 signaling would still attenuate L-type calcium channeldependent CREB phosphorylation. In neurons transfected with CAV3 siRNAs, APDC attenuated depolarization-induced CREB phosphorylation (Fig. 6D). These experiments demonstrate that in hippocampal neurons, CAV3 is essential for ER interactions with $\mathrm{mGluR} 2 / 3$ and signaling to L-type calcium channels, ultimately regulating CREB phosphorylation. As a final experiment, hippocampal neurons were transfected with both sets of siRNAs. As predicted by the previous experiments, inhibition of both CAV1 and CAV3 expression resulted in estradiol having no effect on CREB signaling (Fig. 7).
A

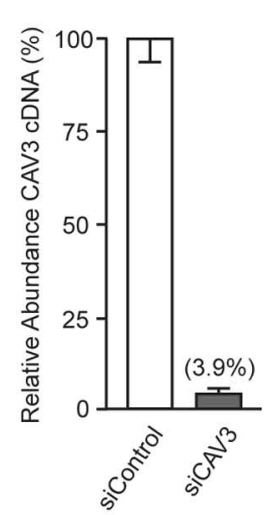

B

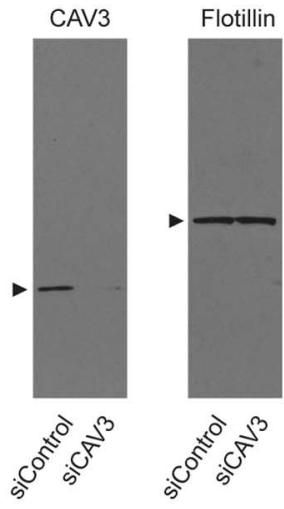

C

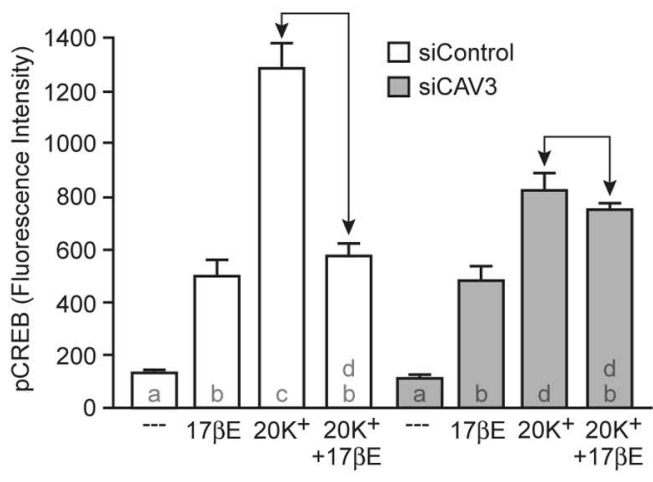

D

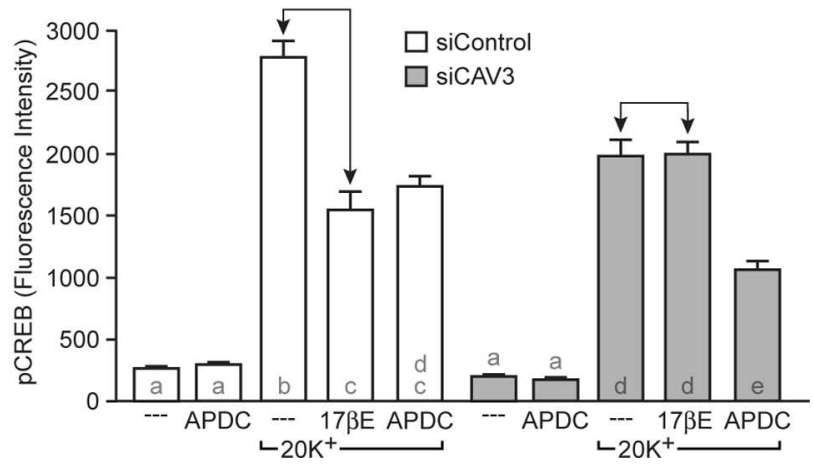

Figure 6. CAV3 is required for estradiol attenuation of L-type calcium channel-dependent CREB phosphorylation. $\boldsymbol{A}$, Transfection of hippocampal cultures with siRNAs targeting CAV3 (siCAV3) resulted in an $\sim 96 \%$ knockdown in CAV3 mRNA. $B$, CAV3 protein expression was also reduced after transfection of siCAV3. C, Estradiol attenuation of depolarization-induced CREB phosphorylation was absent in siCAV3-transfected neurons $(F=49.11)$. Notably, depolarization-induced CREB phosphorylation was also attenuated. D, Activation of $\mathrm{mGluR2} / 3$ with APDC still reduced L-type calcium channel-dependent CREB phosphorylation after transfection of siCAV3 $(F=104.9)$, indicating the actions of siCAV3 were specific to the effects of estradiol. $17 \beta \mathrm{E}, 17 \beta$-Estradiol.

\section{Discussion}

The influence of estradiol on brain function has classically been conceived as a slow process requiring activation of intracellular receptors. However, recent discoveries have determined that estrogens can also rapidly trigger signaling events, affecting a broad spectrum of neuronal processes by acting at the membrane surface. Many of these membrane signaling events are initiated by membrane-associated $\operatorname{ER} \alpha$ and ER $\beta$ (for review, see McCarthy, 2004). Yet, the mechanism(s) by which these traditionally conceived nuclear receptors act at the neuronal surface has remained a mystery. Here we provide 


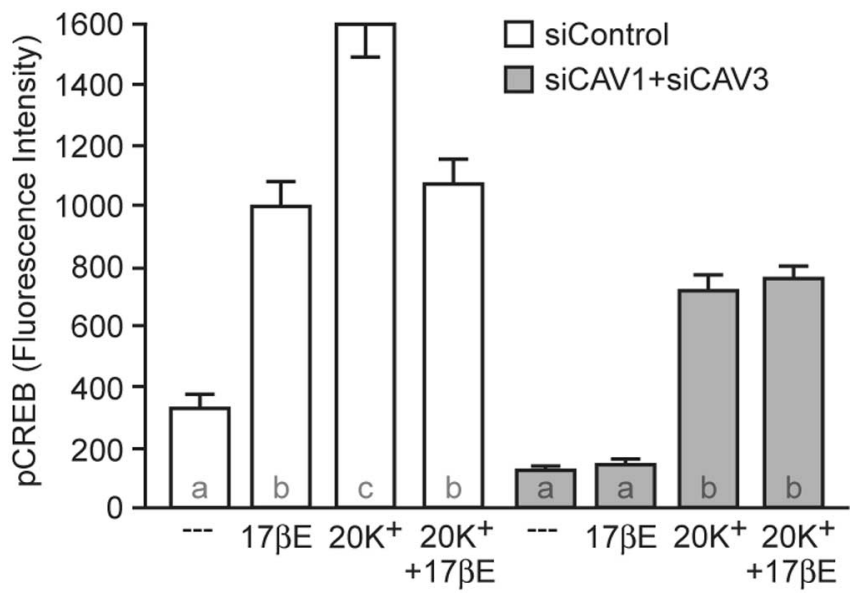

Figure 7. Inhibiting the expression of both CAV1 and CAV3 blocks the bidirectional effects of estradiol. Transfection of hippocampal neurons with siCAV1 and siCAV3 eliminates both estradiol-induced CREB phosphorylation and estradiol-induced attenuation of L-type calcium channel-mediated CREB phosphorylation $(F=50.76)$. 17 $\beta \mathrm{E}, 17 \beta$-Estradiol.

data that caveolin proteins are essential for membrane ER activation of mGluR signaling.

Based on our current experiments and previous work described below, we hypothesize that CAV1 is responsible for the trafficking and/or clustering of $\mathrm{ER} \alpha$ with mGluR1a, whereas CAV3 affords the same role of functionally compartmentalizing $\mathrm{ER} \alpha$ and $\mathrm{ER} \beta$ with $\mathrm{mGluR} 2 / 3$ and L-type calcium channels. However, although our experiments demonstrate the importance of caveolin proteins in ER to mGluR signaling, they do not distinguish the precise mechanism of action. It is also important to note that the dominant-negative and siRNA experiments did not always generate the identical result. For example, depolarization-induced CREB phosphorylation was only affected by siRNAs targeting CAV3. This again suggests some caution when interpreting the data, because multiple signaling systems were most likely affected by the experimental manipulations. As such, our future studies will examine the particular role caveolins play in regulating the membrane actions of estradiol within the CNS.

Along with their function as structural units in the biogenesis of caveolae, caveolin proteins have been demonstrated to play a crucial role in the anchoring and compartmentalization of various signaling molecules within these subcellular compartments (for review, see Williams and Lisanti, 2004). Both CAV1 and CAV3 independently form caveolae (Kirkham et al., 2005), whereas CAV2 appears to facilitate the assembly of CAV1-containing caveolae (Scherer et al., 1997; Li et al., 1998; Scheiffele et al., 1998; Das et al., 1999). Importantly, CAV1 and CAV3 act to form discrete subcellular signaling compartments (Parton et al., 1997), which may be the basis by which we were able to differentially regulate the two estrogensensitive signaling pathways.

In non-neuronal cells, a biological link has been established between CAV1 and ER $\alpha$ (Razandi et al., 2002, 2003), most notably through the identification of S522A ER $\alpha$, also used in the present study. Extensively characterized in $\mathrm{CHO}$ and MCF-7 cells, S522A ER $\alpha$ acts as a dominant negative against membrane-initiated effects of estradiol, because of its inability to bind CAV1. Transfection of S522A ER $\alpha$ led to a significant decrease in membrane-localized $\operatorname{ER} \alpha$, its colocalization with CAV1, and its effectiveness to stimulate rapid signaling cas- cades. Interestingly, the mutant ER is still fully functional when measuring ERE-mediated gene expression (Razandi et al., 2003). Consistent with previous studies, we found S522A $\mathrm{ER} \alpha$ to block estradiol-induced CREB phosphorylation in hippocampal neurons. Yet, the ability of the ER $\alpha$ agonist PPT to still attenuate L-type calcium channel-dependent CREB phosphorylation after expression of S522A ER $\alpha$ demonstrates that not all processes initiated by estrogen and ER $\alpha$ at the membrane surface will be affected by this construct. This idea was also previously outlined by Acconcia et al. (2005). Our data also demonstrate that estrogen-dependent signaling reliant on CAV3 is spared and suggest that particular serine residue is not essential for ERs to functionally interact with CAV3. Future experiments will be required to determine whether $\mathrm{ER} \alpha$ and $\mathrm{ER} \beta$ directly bind CAV 3 and, if so, the specific structural determinants underlying that interaction.

Various other cell-signaling molecules are reliant on caveolin proteins for proper localization and function. Our results are consistent with previous work suggesting a molecular and functional interaction between CAV1 and mGluRla (Burgueno et al., 2004), whereas CAV3 is necessary for the proper localization and functioning of L-type calcium channels (Balijepalli et al., 2006; Couchoux et al., 2007). Specifically, these data parallel our findings in that CAV1 is essential for $\mathrm{ER} \alpha$ activation of mGluR1a, leading to MAPK-dependent CREB phosphorylation, whereas CAV3 is necessary for $\mathrm{ER} \alpha / \mathrm{ER} \beta$ activation of $\mathrm{mGluR} 2 / 3$, resulting in an attenuation of L-type calcium channel-dependent CREB phosphorylation.

Although our results suggest caveolin proteins play an important role in neuroendocrine function, it was, in fact, only recently that these proteins were identified in brain (Cameron et al., 1997; Galbiati et al., 1998; Ikezu et al., 1998b; Mikol et al., 1999). Since then, a wealth of information regarding caveolins and their influence on brain function has emerged. Topics include, but are not limited to, caveolin regulation of synaptic strength, motor control, and Alzheimer's disease (Ikezu et al., 1998a; Nishiyama et al., 1999; Braun and Madison, 2000; Arvanitis et al., 2004; Gaudreault et al., 2004; Trushina et al., 2006). Group I and II mGluRs are also known to be ubiquitously expressed throughout the CNS (Shigemoto and Mizuno, 2000). Within the hippocampus, mGluRs regulate a variety of processes related to learning and memory (Bashir et al., 1993a,b; Weiler and Greenough, 1993; Lu et al., 1997; Bortolotto et al., 1999; Huber et al., 2000; Raymond et al., 2000), although mGluRs mediate various other functions when activated in other brain regions (Anwyl, 1999). Interestingly, many of these processes influenced by both caveolins and mGluRs are also under the regulation of estrogens (McEwen and Alves, 1999). The functional commonalities between caveolin-, mGluR-, and estrogen-sensitive signaling processes may be through the activation of membrane signaling complexes in which all three take part. Thus, we hypothesize that the regulation of hippocampal CREB phosphorylation is only one of many estrogen-sensitive cellular processes that will ultimately be found to use these signaling proteins. In addition, estrogens directly regulate the expression of caveolins (Zschocke et al., 2002), providing a secondary level of interaction between the steroid and the scaffolding proteins.

As in our previous study (Boulware et al., 2005), we have used an in vitro system to delineate two distinct estradiol-sensitive signaling pathways that ultimately lead to the regulation of CREB. Our work follows that of others who have demonstrated this transcription factor to be estrogen sensitive in a variety of 
model systems (Gu et al., 1996; Zhou et al., 1996; Murphy and Segal, 1997; Wade and Dorsa, 2003; Abizaid et al., 2004; Choi et al., 2004; Lee et al., 2004; Wu et al., 2005; Zhao et al., 2005; Zhou et al., 2005; Szego et al., 2006; Sharma et al., 2007). Specifically, we found membrane ERs to activate mGluRs, which is dependent on caveolin function. And although our model affords great experimental control, corroboration of our results, especially in vivo, would provide an overall physiological relevance to our findings. A recent study by Dewing et al. (2007) demonstrates that within the arcuate nucleus, ER $\alpha$ activation of mGluRla is essential for the full display of lordosis. In addition, estradiol-induced regulation of L-type calcium channels in both dorsal root ganglia and striatum is dependent on ER activation of mGluR2/3 (Chaban et al., 2007; D. Grove-Strawser and P. G. Mermelstein, unpublished observations). These results are not only consistent with our findings but also suggest that within different neuronal populations the effects of estradiol may be dependent on one particular signaling pathway. In addition, studies using knock-out mice suggest that $\mathrm{ER} \beta$ can also trigger CREB phosphorylation in neurons lacking $\mathrm{ER} \alpha$ (Abraham et al., 2003). It would be interesting to determine whether in neurons lacking $\mathrm{ER} \alpha, \mathrm{ER} \beta$-induced CREB phosphorylation is also dependent on mGluRla and CAV1. This would suggest that neurons are capable of using either ER to regulate distinct signaling pathways. Although it is currently unclear what the physiological consequences would be when using $\mathrm{ER} \alpha$ versus $\mathrm{ER} \beta$ to stimulate these signaling cascades, it potentially adds another layer of regulation and complexity to membrane ER function.

In summary, our results demonstrate a pivotal role for caveolin proteins in rapid, membrane-initiated effects of estradiol within the hippocampus. Specifically, CAV1 and CAV3 appear to be responsible for the functional isolation of two distinct signaling pathways that lead to opposing influences on the transcription factor CREB. We hypothesize that this segregation is achieved via CAV1- and CAV3-contaning caveolae, each congregating distinct signaling molecules into functional cellular microdomains. Furthermore, because of the diversity of membrane ER effects throughout the nervous system, as well as overlap between membrane estrogen action and caveolin function, our results may be of importance in more widespread neuroendocrine function.

\section{References}

Abizaid A, Mezei G, Horvath TL (2004) Estradiol enhances light-induced expression of transcription factors in the SCN. Brain Res 1010:35-44.

Abraham IM, Han SK, Todman MG, Korach KS, Herbison AE (2003) Estrogen receptor $\beta$ mediates rapid estrogen actions on gonadotropinreleasing hormone neurons in vivo. J Neurosci 23:5771-5777.

Abraham IM, Todman MG, Korach KS, Herbison AE (2004) Critical in vivo roles for classical estrogen receptors in rapid estrogen actions on intracellular signaling in mouse brain. Endocrinology 145:3055-3061.

Acconcia F, Ascenzi P, Bocedi A, Spisni E, Tomasi V, Trentalance A, Visca P, Marino M (2005) Palmitoylation-dependent estrogen receptor alpha membrane localization: regulation by 17beta-estradiol. Mol Biol Cell 16:231-237.

Anwyl R (1999) Metabotropic glutamate receptors: electrophysiological properties and role in plasticity. Brains Res Rev 29:83-120.

Arvanitis DN, Wang H, Bagshaw RD, Callahan JW, Boggs JM (2004) Membrane-associated estrogen receptor and caveolin-1 are present in central nervous system myelin and oligodendrocyte plasma membranes. J Neurosci Res 75:603-613.

Balijepalli RC, Foell JD, Hall DD, Hell JW, Kamp TJ (2006) Localization of cardiac L-type $\mathrm{Ca}(2+)$ channels to a caveolar macromolecular signaling complex is required for beta(2)-adrenergic regulation. Proc Natl Acad Sci USA 103:7500-7505.

Bashir ZI, Bortolotto ZA, Davies CH, Berretta N, Irving AJ, Seal AJ, Henley
JM, Jane DE, Watkins JC, Collingridge GL (1993a) Induction of LTP in the hippocampus needs synaptic activation of glutamate metabotropic receptors. Nature 363:347-350.

Bashir ZI, Jane DE, Sunter DC, Watkins JC, Collingridge GL (1993b) Metabotropic glutamate receptors contribute to the induction of longterm depression in the CA1 region of the hippocampus. Eur J Pharmacol 239:265-266.

Belcher SM, Zsarnovszky A (2001) Estrogenic actions in the brain: estrogen, phytoestrogens, and rapid intracellular signaling mechanisms. J Pharmacol Exp Ther 299:408-414.

Bortolotto ZA, Fitzjohn SM, Collingridge GL (1999) Roles of metabotropic glutamate receptors in LTP and LTD in the hippocampus. Curr Opin Neurobiol 9:299-304.

Boulware MI, Weick JP, Becklund BR, Kuo SP, Groth RD, Mermelstein PG (2005) Estradiol activates group I and II metabotropic glutamate receptor signaling, leading to opposing influences on cAMP response elementbinding protein. J Neurosci 25:5066-5078.

Braun JE, Madison DV (2000) A novel SNAP25-caveolin complex correlates with the onset of persistent synaptic potentiation. J Neurosci 20:5997-6006.

Burgueno J, Canela EI, Mallol J, Lluis C, Franco R, Ciruela F (2004) Mutual regulation between metabotropic glutamate type lalpha receptor and caveolin proteins: from traffick to constitutive activity. Exp Cell Res 300:23-34

Cameron PL, Ruffin JW, Bollag R, Rasmussen H, Cameron RS (1997) Identification of caveolin and caveolin-related proteins in the brain. J Neurosci 17:9520-9535.

Chaban VV, Li J, McDonald JS, Rapkin A, Micevych P (2007) Estradiol attenuates ATP-induced increase of intracellular calcium through group II metabotropic glutamate receptors in rat DRG neurons. Soc Neurosci Abstr, in press.

Chambliss KL, Yuhanna IS, Mineo C, Liu P, German Z, Sherman TS, Mendelsohn ME, Anderson RG, Shaul PW (2000) Estrogen receptor alpha and endothelial nitric oxide synthase are organized into a functional signaling module in caveolae. Circ Res 87:E44-E52.

Choi YC, Lee JH, Hong KW, Lee KS (2004) 17 Beta-estradiol prevents focal cerebral ischemic damages via activation of Akt and CREB in association with reduced PTEN phosphorylation in rats. Fundam Clin Pharmacol 18:547-557.

Couchoux H, Allard B, Legrand C, Jacquemond V, Berthier C (2007) Loss of caveolin-3 induced by the dystrophy-associated P104L mutation impairs L-type calcium channel function in mouse skeletal muscle cells. J Physiol (Lond) 580:745-754.

Couse JF, Korach KS (1999) Estrogen receptor null mice: what have we learned and where will they lead us? Endocr Rev 20:358-417.

Das K, Lewis RY, Scherer PE, Lisanti MP (1999) The membrane-spanning domains of caveolins- 1 and -2 mediate the formation of caveolin heterooligomers. Implications for the assembly of caveolae membranes in vivo. J Biol Chem 274:18721-18728.

Deisseroth K, Heist EK, Tsien RW (1998) Translocation of calmodulin to the nucleus supports CREB phosphorylation in hippocampal neurons. Nature 392:198-202.

Dewing P, Boulware MI, Sinchack K, Christensen A, Mermelstein PG, Micevych P (2007) Membrane ER $\alpha$ interacts with mGluRla to modulate female sexual receptivity. J Neurosci 27:9294-9300.

Escande A, Pillon A, Servant N, Cravedi JP, Larrea F, Muhn P, Nicolas JC, Cavailles V, Balaguer P (2006) Evaluation of ligand selectivity using reporter cell lines stably expressing estrogen receptor alpha or beta. Biochem Pharmacol 71:1459-1469.

Galbiati F, Volonte D, Gil O, Zanazzi G, Salzer JL, Sargiacomo M, Scherer PE, Engelman JA, Schlegel A, Parenti M, Okamoto T, Lisanti MP (1998) Expression of caveolin-1 and -2 in differentiating PC12 cells and dorsal root ganglion neurons: caveolin-2 is up-regulated in response to cell injury. Proc Natl Acad Sci USA 95:10257-10262.

Gaudreault SB, Dea D, Poirier J (2004) Increased caveolin-1 expression in Alzheimer's disease brain. Neurobiol Aging 25:753-759.

Gaudreault SB, Blain JF, Gratton JP, Poirier J (2005) A role for caveolin-1 in post-injury reactive neuronal plasticity. J Neurochem 92:831-839.

Gu G, Rojo AA, Zee MC, Yu J, Simerly RB (1996) Hormonal regulation of CREB phosphorylation in the anteroventral periventricular nucleus. J Neurosci 16:3035-3044.

Huber KM, Kayser MS, Bear MF (2000) Role for rapid dendritic protein 
synthesis in hippocampal mGluR-dependent long-term depression. Science 288:1254-1257.

Ikezu T, Trapp BD, Song KS, Schlegel A, Lisanti MP, Okamoto T (1998a) Caveolae, plasma membrane microdomains for alpha-secretasemediated processing of the amyloid precursor protein. J Biol Chem 273:10485-10495.

Ikezu T, Ueda H, Trapp BD, Nishiyama K, Sha JF, Volonte D, Galbiati F, Byrd AL, Bassell G, Serizawa H, Lane WS, Lisanti MP, Okamoto T (1998b) Affinity-purification and characterization of caveolins from the brain: differential expression of caveolin-1, -2 , and -3 in brain endothelial and astroglial cell types. Brain Res 804:177-192.

Kelly MJ, Wagner EJ (1999) Estrogen modulation of G-protein-coupled receptors. Trends Endocrinol Metab 10:369-374.

Kelly MJ, Lagrange AH, Wagner EJ, Ronnekleiv OK (1999) Rapid effects of estrogen to modulate $\mathrm{G}$ protein-coupled receptors via activation of protein kinase A and protein kinase C pathways. Steroids 64:64-75.

Kim HP, Lee JY, Jeong JK, Bae SW, Lee HK, Jo I (1999) Nongenomic stimulation of nitric oxide release by estrogen is mediated by estrogen receptor alpha localized in caveolae. Biochem Biophys Res Commun 263:257-262.

Kirkham M, Fujita A, Chadda R, Nixon SJ, Kurzchalia TV, Sharma DK, Pagano RE, Hancock JF, Mayor S, Parton RG (2005) Ultrastructural identification of uncoated caveolin-independent early endocytic vehicles. J Cell Biol 168:465-476.

Klinge CM (2001) Estrogen receptor interaction with estrogen response elements. Nucleic Acids Res 29:2905-2919.

Krajewska WM, Maslowska I (2004) Caveolins: structure and function in signal transduction. Cell Mol Biol Lett 9:195-220.

Lee H, Park DS, Razani B, Russell RG, Pestell RG, Lisanti MP (2002) Caveolin-1 mutations (P132L and null) and the pathogenesis of breast cancer: caveolin-1 (P132L) behaves in a dominant-negative manner and caveolin-1 (-/-) null mice show mammary epithelial cell hyperplasia. Am J Pathol 161:1357-1369.

Lee SJ, Campomanes CR, Sikat PT, Greenfield AT, Allen PB, McEwen BS (2004) Estrogen induces phosphorylation of cyclic AMP response element binding (pCREB) in primary hippocampal cells in a timedependent manner. Neuroscience 124:549-560.

Levin ER (2002) Cellular functions of plasma membrane estrogen receptors. Steroids 67:471-475.

Li S, Galbiati F, Volonte D, Sargiacomo M, Engelman JA, Das K, Scherer PE, Lisanti MP (1998) Mutational analysis of caveolin-induced vesicle formation. Expression of caveolin-1 recruits caveolin-2 to caveolae membranes. FEBS Lett 434:127-134.

Lu YM, Jia Z, Janus C, Henderson JT, Gerlai R, Wojtowicz JM, Roder JC (1997) Mice lacking metabotropic glutamate receptor 5 show impaired learning and reduced CA1 long-term potentiation (LTP) but normal CA3 LTP. J Neurosci 17:5196-5205.

McCarthy MM (2004) Out with the new, in with the old: classical estrogen receptors mediate novel estradiol actions in brain. Endocrinology 145:3053-3054.

McEwen BS, Alves SE (1999) Estrogen actions in the central nervous system. Endocr Rev 20:279-307.

Mermelstein PG, Bito H, Deisseroth K, Tsien RW (2000) Critical dependence of cAMP response element-binding protein phosphorylation on L-type calcium channels supports a selective response to EPSPs in preference to action potentials. J Neurosci 20:266-273.

Meyers MJ, Sun J, Carlson KE, Marriner GA, Katzenellenbogen BS, Katzenellenbogen JA (2001) Estrogen receptor-beta potency-selective ligands: structure-activity relationship studies of diarylpropionitriles and their acetylene and polar analogues. J Med Chem 44:4230-4251.

Mikol DD, Hong HL, Cheng HL, Feldman EL (1999) Caveolin-1 expression in Schwann cells. Glia 27:39-52.

Murphy DD, Segal M (1997) Morphological plasticity of dendritic spines in central neurons is mediated by activation of cAMP response element binding protein. Proc Natl Acad Sci USA 94:1482-1487.

Nishiyama K, Trapp BD, Ikezu T, Ransohoff RM, Tomita T, Iwatsubo T, Kanazawa I, Hsiao KK, Lisanti MP, Okamoto T (1999) Caveolin-3 upregulation activates $\beta$-secretase-mediated cleavage of the amyloid precursor protein in Alzheimer's disease. J Neurosci 19:6538-6548.

Ohsawa Y, Toko H, Katsura M, Morimoto K, Yamada H, Ichikawa Y, Murakami T, Ohkuma S, Komuro I, Sunada Y (2004) Overexpression of P104L mutant caveolin-3 in mice develops hypertrophic cardiomyopathy with enhanced contractility in association with increased endothelial nitric oxide synthase activity. Hum Mol Genet 13:151-157.

Parton RG, Way M, Zorzi N, Stang E (1997) Caveolin-3 associates with developing T-tubules during muscle differentiation. J Cell Biol 136:137-154.

Qiu J, Bosch MA, Tobias SC, Grandy DK, Scanlan TS, Ronnekleiv OK, Kelly MJ (2003) Rapid signaling of estrogen in hypothalamic neurons involves a novel G-protein-coupled estrogen receptor that activates protein kinase C. J Neurosci 23:9529-9540.

Raymond CR, Thompson VL, Tate WP, Abraham WC (2000) Metabotropic glutamate receptors trigger homosynaptic protein synthesis to prolong long-term potentiation. J Neurosci 20:969-976.

Razandi M, Pedram A, Greene GL, Levin ER (1999) Cell membrane and nuclear estrogen receptors (ERs) originate from a single transcript: studies of ERalpha and ERbeta expressed in Chinese hamster ovary cells. Mol Endocrinol 13:307-319.

Razandi M, Oh P, Pedram A, Schnitzer J, Levin ER (2002) ERs associate with and regulate the production of caveolin: implications for signaling and cellular actions. Mol Endocrinol 16:100-115.

Razandi M, Alton G, Pedram A, Ghonshani S, Webb P, Levin ER (2003) Identification of a structural determinant necessary for the localization and function of estrogen receptor alpha at the plasma membrane. Mol Cell Biol 23:1633-1646.

Revankar CM, Cimino DF, Sklar LA, Arterburn JB, Prossnitz ER (2005) A transmembrane intracellular estrogen receptor mediates rapid cell signaling. Science 307:1625-1630.

Scheiffele P, Verkade P, Fra AM, Virta H, Simons K, Ikonen E (1998) Caveolin-1 and -2 in the exocytic pathway of MDCK cells. J Cell Biol 140:795-806.

Scherer PE, Lewis RY, Volonte D, Engelman JA, Galbiati F, Couet J, Kohtz DS, van Donselaar E, Peters P, Lisanti MP (1997) Cell-type and tissuespecific expression of caveolin-2. Caveolins 1 and 2 co-localize and form a stable hetero-oligomeric complex in vivo. J Biol Chem 272:29337-29346.

Schlegel A, Wang C, Katzenellenbogen BS, Pestell RG, Lisanti MP (1999) Caveolin-1 potentiates estrogen receptor alpha (ERalpha) signaling. caveolin-1 drives ligand-independent nuclear translocation and activation of ERalpha. J Biol Chem 274:33551-33556.

Schlegel A, Wang C, Pestell RG, Lisanti MP (2001) Ligand-independent activation of oestrogen receptor alpha by caveolin-1. Biochem J 359:203-210.

Sharma K, Mehra RD, Dhar P, Vij U (2007) Chronic exposure to estrogen and tamoxifen regulates synaptophysin and phosphorylated cAMP response element-binding (CREB) protein expression in CA1 of ovariectomized rat hippocampus. Brain Res 1132:10-19.

Shigemoto R, Mizuno N (2000) Metabotropic glutamate receptorsimmunocytochemical and in situ hybridization analysis. Amsterdam: Elsevier.

Szego EM, Barabas K, Balog J, Szilagyi N, Korach KS, Juhasz G, Abraham IM (2006) Estrogen induces estrogen receptor $\alpha$-dependent cAMP response element-binding protein phosphorylation via mitogen activated protein kinase pathway in basal forebrain cholinergic neurons in vivo. J Neurosci 26:4104-4110.

Toran-Allerand CD, Guan X, MacLusky NJ, Horvath TL, Diano S, Singh M, Connolly Jr ES, Nethrapalli IS, Tinnikov AA (2002) ER-X: a novel, plasma membrane-associated, putative estrogen receptor that is regulated during development and after ischemic brain injury. J Neurosci 22:8391-8401.

Trushina E, Du Charme J, Parisi J, McMurray CT (2006) Neurological abnormalities in caveolin-1 knock out mice. Behav Brain Res 172:24-32.

Vasudevan N, Kow LM, Pfaff D (2005) Integration of steroid hormone initiated membrane action to genomic function in the brain. Steroids 70:388-396.

Wade CB, Dorsa DM (2003) Estrogen activation of cyclic adenosine 5' monophosphate response element-mediated transcription requires the extracellularly regulated kinase/mitogen-activated protein kinase pathway. Endocrinology 144:832-838.

Wade CB, Robinson S, Shapiro RA, Dorsa DM (2001) Estrogen receptor (ER)alpha and ERbeta exhibit unique pharmacologic properties when coupled to activation of the mitogen-activated protein kinase pathway. Endocrinology 142:2336-2342.

Watson CS, Campbell CH, Gametchu B (1999) Membrane oestrogen recep- 
tors on rat pituitary tumour cells: immuno-identification and responses to oestradiol and xenoestrogens. Exp Physiol 84:1013-1022.

Weick JP, Groth RD, Isaksen AL, Mermelstein PG (2003) Interactions with PDZ proteins are required for L-type calcium channels to activate cAMP response element-binding protein-dependent gene expression. J Neurosci 23:3446-3456.

Weiler IJ, Greenough WT (1993) Metabotropic glutamate receptors trigger postsynaptic protein synthesis. Proc Natl Acad Sci USA 90:7168-7171.

Williams TM, Lisanti MP (2004) The caveolin proteins. Genome Biol 5:214. Wu TW, Wang JM, Chen S, Brinton RD (2005) 17Beta-estradiol induced $\mathrm{Ca} 2+$ influx via L-type calcium channels activates the Src/ERK/cyclicAMP response element binding protein signal pathway and BCL-2 expression in rat hippocampal neurons: a potential initiation mechanism for estrogen-induced neuroprotection. Neuroscience $135: 59-72$
Zhao L, Chen S, Ming Wang J, Brinton RD (2005) 17beta-estradiol induces $\mathrm{Ca} 2+$ influx, dendritic and nuclear $\mathrm{Ca} 2+$ rise and subsequent cyclic AMP response element-binding protein activation in hippocampal neurons: a potential initiation mechanism for estrogen neurotrophism. Neuroscience 132:299-311.

Zhou J, Zhang H, Cohen RS, Pandey SC (2005) Effects of estrogen treatment on expression of brain-derived neurotrophic factor and cAMP response element-binding protein expression and phosphorylation in rat amygdaloid and hippocampal structures. Neuroendocrinology 81:294-310.

Zhou Y, Watters JJ, Dorsa DM (1996) Estrogen rapidly induces the phosphorylation of the cAMP response element binding protein in rat brain. Endocrinology 137:2163-2166.

Zschocke J, Manthey D, Bayatti N, van der Burg B, Goodenough S, Behl C (2002) Estrogen receptor alpha-mediated silencing of caveolin gene expression in neuronal cells. J Biol Chem 277:38772-38780. 